\title{
The role of belief in the regulation and reporting of memories
}

Citation for published version (APA):

Clark, A. (2017). The role of belief in the regulation and reporting of memories. [Doctoral Thesis,

Maastricht University, Department of Psychology, University of Portsmouth Portsmouth, United Kingdom.]. Datawyse / Universitaire Pers Maastricht. https://doi.org/10.26481/dis.20170628ac

Document status and date:

Published: 01/01/2017

DOI:

10.26481/dis.20170628ac

Document Version:

Publisher's PDF, also known as Version of record

\section{Please check the document version of this publication:}

- A submitted manuscript is the version of the article upon submission and before peer-review. There can be important differences between the submitted version and the official published version of record.

People interested in the research are advised to contact the author for the final version of the publication, or visit the DOI to the publisher's website.

- The final author version and the galley proof are versions of the publication after peer review.

- The final published version features the final layout of the paper including the volume, issue and page numbers.

Link to publication

\footnotetext{
General rights rights.

- You may freely distribute the URL identifying the publication in the public portal. please follow below link for the End User Agreement:

www.umlib.nl/taverne-license

Take down policy

If you believe that this document breaches copyright please contact us at:

repository@maastrichtuniversity.nl

providing details and we will investigate your claim.
}

Copyright and moral rights for the publications made accessible in the public portal are retained by the authors and/or other copyright owners and it is a condition of accessing publications that users recognise and abide by the legal requirements associated with these

- Users may download and print one copy of any publication from the public portal for the purpose of private study or research.

- You may not further distribute the material or use it for any profit-making activity or commercial gain

If the publication is distributed under the terms of Article $25 \mathrm{fa}$ of the Dutch Copyright Act, indicated by the "Taverne" license above, 


\section{Abstract}

Recent research demonstrates that believing that an event occurred and recollecting an event are distinct components of remembering the past. The over-arching aim of this thesis was to examine whether omission errors in memory reports can be explained by the attenuation of belief in those memories. Specifically, we examined whether omission errors are characterised by lower belief ratings. Previous research suggests that omission errors can be elicited using suggestive and misleading post-event information. Factors such as social feedback, contradictory evidence and event implausibility are also commonly reported reasons for people attenuating their belief that events in their past actually occurred. In Experiments 1 and 2, we sought to elicit omission errors using a procedure adapted from Wright et al. (2001). Participants saw a number of scenes, each showing a collection of household items. After a free recall test where participants had to recall as many items as they could from each scene, participants were either represented with the scenes (Expt. 1) or the experimenter read aloud to the participants the items they had recalled (Expt. 2). In these re-presented scenes, some of the items which were originally presented to the participants were withheld. The results showed that re-presenting participants with either the original stimuli (Expt. 1) or repeating back to participants the items they had recalled (Expt. 2) with some items withheld, did not result in participants attenuating their belief that they had previously seen these items. Furthermore, we did not find substantial evidence that these items were even omitted (at a higher rate) as predicted from previous research (Wright et al., 2001). In Experiments 3 and 4, participants' memories of items (Expt. 3) or actions (Expt. 4) were challenged by a confederate (Expt. 3 \& 4), or by the experimenter (Expt. 4) providing social feedback. The results showed that social feedback resulted in omission errors and the attenuation of belief. However, we also found that memory ratings for omitted memories were lower than reported memories. In the discussion of our results, we highlight the important link between social feedback, omission errors and the attenuation of belief. 